\title{
Application of Case-Teaching to College Auditing Teaching
}

\author{
Hu xiao qing \\ Shandong University of Science and Technology \\ 1605406751@qq.com
}

Keywords: Case-teaching; College;Auditing Teaching;

\begin{abstract}
With its unique innovation method, Case-teaching is now gradually applied to College Auditing Teaching. However, problems do exits in the practical process. Based on the application status, this essay aims at putting forward main countermeasures to perfect College Auditing Teaching from four aspects: clearing the goal of auditor training, reforming the conventional auditing teaching method, cultivating distinguished faculty, establishing sophisticated teaching system.
\end{abstract}

\section{Introduction}

Compared with other disciplines, auditing is more theoretical, practical and permeable. With the rapid development of economy, the profession has received concern from more and more companies along with an increase of the demands of auditors.

As graduators from auditing fail to adapt to the society, the current demand of auditors outstrips the supply ${ }^{[1]}$. Therefore, to cultivate auditors with creativity the society needs, an in-depth exploration of the auditing teaching law is necessary. Innovative thinking and practical abilities are also indispensable in the education of professional knowledge. However, operable guidance in practice has a weak basis, making it difficult for the students to apprehend and master.

The application of Case-teaching is essential with all these facts.

\section{The concept of Case-teaching}

Case-teaching is a teaching method based on cases. Changing the contents of teaching into cases, teachers interpret and analyze the key and difficult points to the students, playing the role of designer, guide and prompter ${ }^{[2]}$.

Developing students' independent thinking and problem solving ability by encouraging them actively engaged in the study and discussion, this teaching method make the class atmosphere easy and live. Welcomed by both teachers and students with its evident effect, Case-teaching received great attention and is now wildly used in education and training.

Procedure is shown in Fig. 1. 


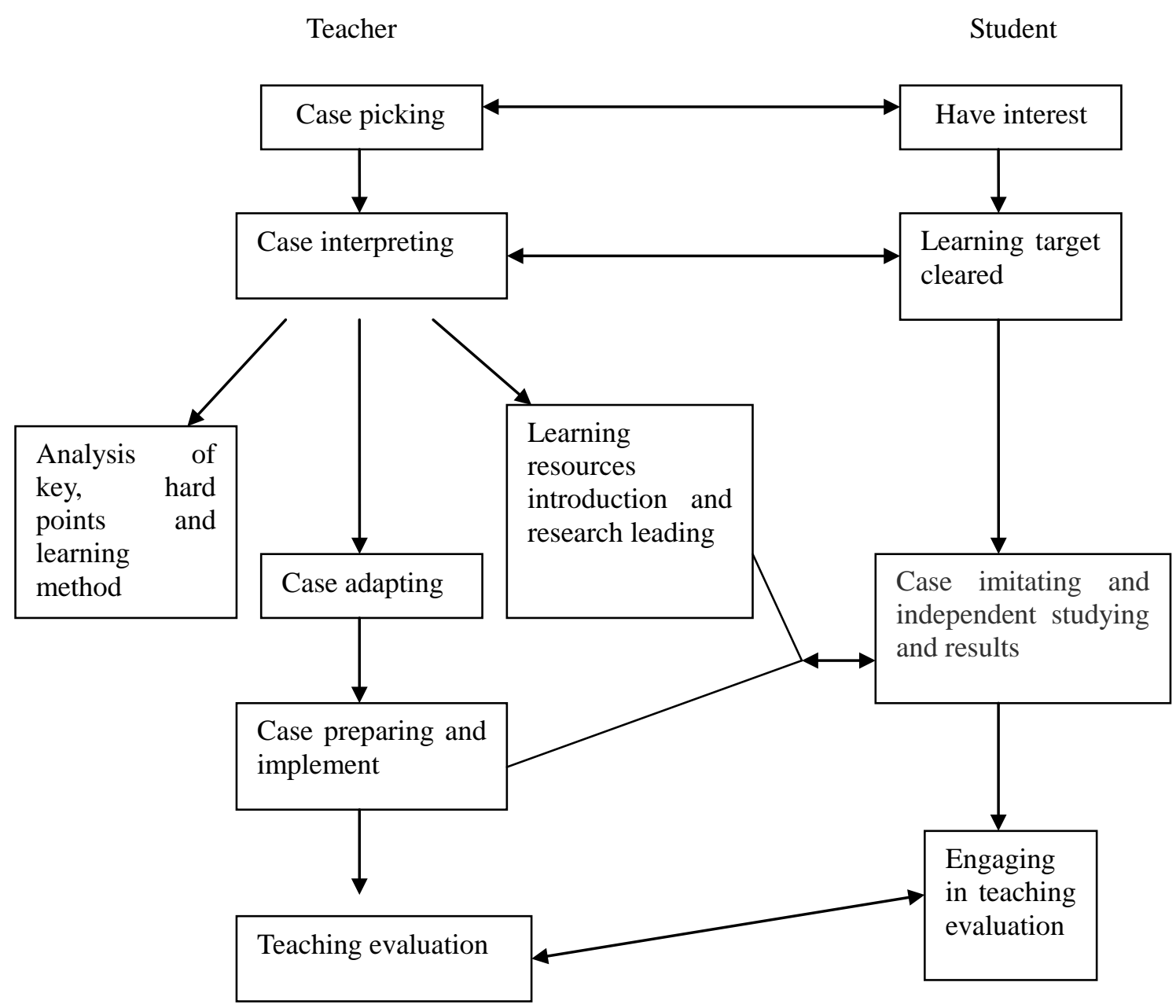

Fig. 1: Procedure of Case-teaching

\section{Problems exit in the practice of Case-teaching}

\subsection{Insufficient auditing cases to meet the demands of teaching}

The implication of Case-teaching relies on the teachers gathering up abundant real cases to revising, modifying and typifying. The quality of auditing cases directly affects the success of teaching. So choosing appropriate cases is vital. Good cases are true, valid and practical, collected by instructors personally through various sources or adapted from surveys. Meanwhile, teachers can have a better control in teaching and achieve better effects.

However, at the initial phase of auditing case studying, there are insufficient cases that can be applied to college teaching[3]. Up to now, published textbooks of auditing mostly lack systematicness, focusing on the processes and results of auditing, and citing cases from abroad that lives out of the real auditing circumstances of China, failing to meet the requirement of Case-teaching.

There are defects in today's auditing cases applied to college teaching. First, domestic cases mostly confined to review and adjust the wrong account, introduce auditing process, adjustments and results, felled far short of auditing thinking and logical thinking, unsuitable for teaching rules and requirements[4]. Second, the too straightforward cases' obvious mistakes are not conducive to students' thinking, while classic and complicated cases from western countries are too difficult to comprehend. Last, the contents of the textbooks are more or less out of date, falling behind the new 
guidelines. Teachers' weak auditing practice participating consciousness, limited chances, and lack of experience in Case-teaching all added difficulty to the promotion of Case-teaching.

\subsection{Students' inability to adapt to the new Case-teaching method with the conventional ones still in use}

Teachers are the leading role in conventional teaching methods with students in passive state. Teachers impart knowledge according to the textbooks, knowing nothing about students' apprehension. This teaching method lasted for a long time, knowing and accepted by both teachers and students[5].

In Case-teaching, focusing on the students, teachers only play a supporting role. It's hard for some students to transform from the already accustomed teaching method to the new Case-teaching. They feel physically and mentally exhausted without preparation. They lack a sense of consciousness, have no activity in previewing the text, no research of relative learning materials, and are reluctant to think questions. In class, they pay little interest to case discussing, unable to take part in, and have no opinions. After class, they cannot summarize the already learned and the assignments are also poor finished. Case-teaching can have little success.

\subsection{Teaching's limited comprehension and teaching experience in Case-teaching}

Case-teaching, which asks for the cooperation and working together of teachers and students, demands the joint efforts of them. Though students are the protagonist, teachers who inspire their ideas through cases also make sense.

Nevertheless, China's Case-teaching is at a starting stage. Teachers, with only a few received professional training, have difficulty in mastering the key points of Case-teaching, which greatly impact the teaching quality. And due to the teaching load of college teachers and other facts, teachers themselves may have little experience in auditing practice, which increased the difficulty of relating theory to practice during cased discussion, not to mention being the guide. The discussion therefore would be apt to stay on the surface of the phenomenon rather than in-depth analyses and arguments, falling far bellow the expected effects.

\section{Countermeasures to perfect College Auditing Teaching}

\subsection{Have a clear goal of auditor training, gather and sum up teaching cases}

With the development of society, auditor training has been gradually valued. According to the data investigation of Talent Resources Market, more and more companies pay attention to their financial standings and have strong demands of professional auditors. And college education aims at turning students into professionals adapted to the society and capable of working.

Relevant education institutions point out that auditing teaching should not only focus on the books and exams, but also on the ability of analyzing and comprehending, knowing the rest of a kind by analogy and drawing inferences, then improving the all-round quality. Case-teaching, now prevalent in College Auditing Teaching, requires the teachers to gather up abundant teaching cases to establish a varied collection.

Generally speaking, a good teaching case should comply with the following characteristics. The first one is practical relevance. The case has to be a real one, while teachers can adapt it to correspond with teaching content; it must meet today's social reality and have no casual assumption. The second character is comprehensive representative. A teaching case must be typical, which can interpret the teaching content and reflect the general characteristic. Relevant teaching content can be enumerated with this case; students can therefore better understand and accept the impressive teaching.

Gathering and adapting teaching cases can be time and energy consuming, it asks for the teachers putting heads together and sharing the information to typify the cases by scientifically 
screening, adapting and rearranging the sources, reflecting the auditing theories and methods, then synthesizing them into systemic and developed teaching case library.

\subsection{Reform the conventional auditing teaching method and carry out Case-teaching mode}

The main method of Case-teaching is that students willingly analyze the cases and actively communicate their own ideas. The teaching environment can provide them opportunities of case preparation and results discussion, students can learn from the study and research of the process, remembering and applying the knowledge and skills.

Teachers, picking out good auditing cases, should design and organize the class. By action researching, teachers arouse students learning enthusiasm, knowing their studies and the teaching progress, finally summarizing problems discovered by students and exploring strategies to improve.

Procedure is shown in Fig. 2.

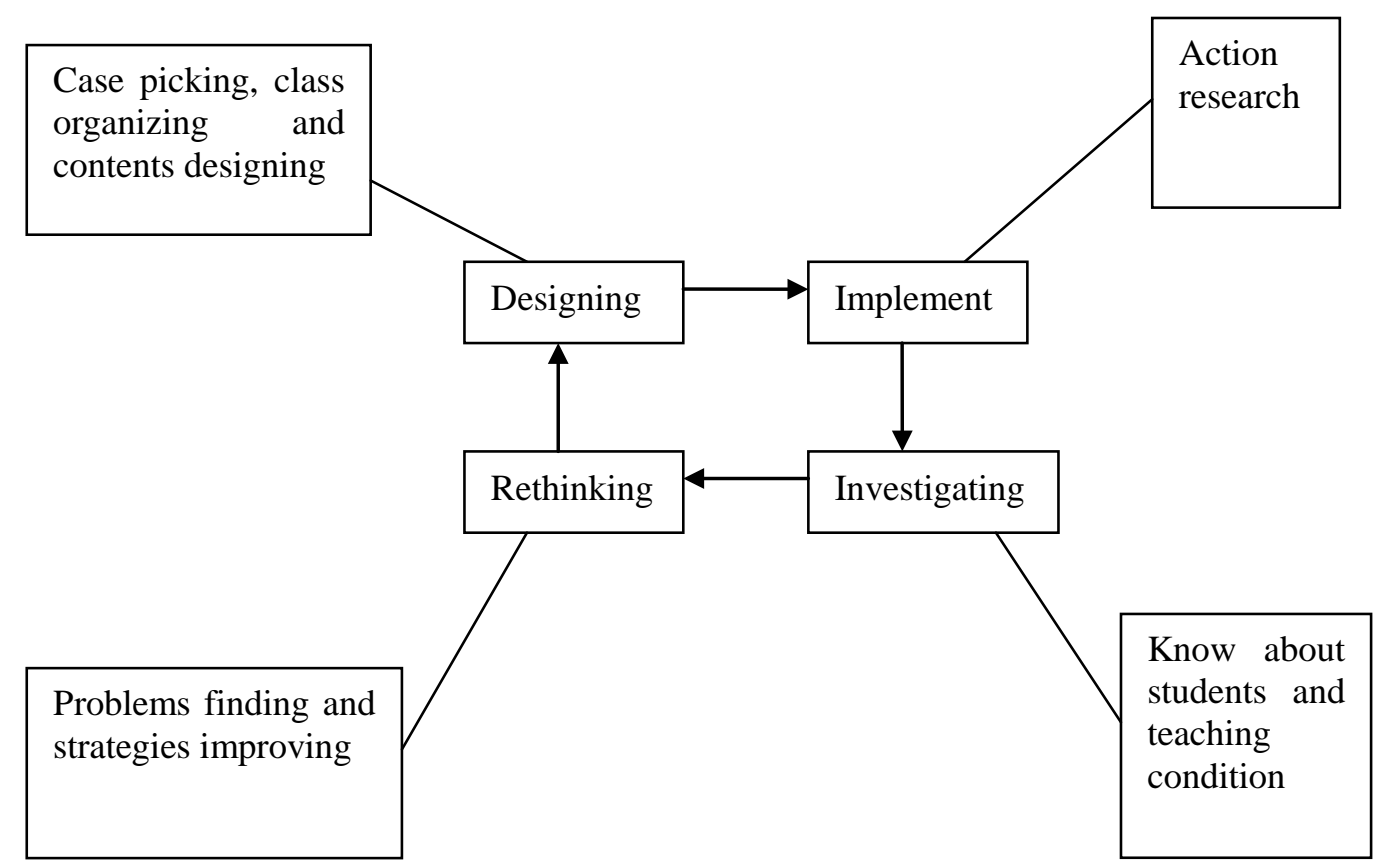

Fig.2: Implement procedure of Case-teaching

Three ways are used to carry out Case-teaching.

First, cultivate students' ability of independent thinking. In the conventional inflexible teaching, students passively accept knowledge from teachers, lacking initiative and activity. Case-teaching, however, with teachers giving students relevant cases, they analyze and think by themselves. Breaking the ice, the class became a carrier of students' information exchanging, improving their communication and interpersonal skills. They can also feel the stress of competition. It is the teachers' job to steer the pressure into motivation, making students aggressive and upward.

Second, cultivate students' own abilities. As competition in every field is so fierce now, it is worth considering for college students how to turn knowledge learned in school into their own abilities. They should not be bound in fetters and restrictions of books, but have their own ideas and opinions. Enterprises all attach importance to efficiency. Students' neglecting their own abilities cultivation will be disadvantageous to their future development, so to the companies. Case-teaching can elevate students' self cultivation, laying a solid foundation for the future.

Third, pay attention to the bi-direction exchange between teachers and students. Communication in conventional teaching is one-way directed, teachers speaking, students listening, with teachers knowing nothing about how much students understand and whether the were they actually listening or not. In Case-teaching, teachers distribute cases to students, leaving them going through all related speculative knowledge. 
By reading related theoretical knowledge, students can independently put forward plans to solve the problem. As his plans ask for the teachers' guiding, this promote the teachers deepen their thinking and adding new content to the teaching according to his apprehension. This bi-direction teaching method places higher requirements on teachers.

\subsection{Cultivate distinguished faculty, improve the teaching quality}

College auditing teaching have high requirements on teachers, not only should they gather up real cases and adapt them into teaching ones, but also have remarkable practical experience. Now most college auditing teachers directly went to work after graduation, their teaching contents are therefore from books rather than their own experience.

As teachers rarely contact with auditing practice, they fail to analyze real cases easily in class. The insipid teaching fails to attract students' attention, not to mention understanding. It is crucial to develop the teachers and let them have regular training. Teachers should also take part in practice in auditing departments, accounting films and other related institutions regularly. This would help them master the first hand information to prepare for the teaching cases, and improve teaching quality. Besides, schools can invite experienced auditing experts to have lectures to broaden students' horizon, making up for the deficiency of class.

\subsection{Establish a sophisticated teaching system, improve students' learning initiative}

Teachers play the leading role in the conventional class teaching, and students negatively accept the knowledge. The dull, oppressive class atmosphere and insipid teaching content fail to inspire students' innovative thinking and are disadvantageous to their characters and pioneering spirit developing. This all lead to their lack of experience, incapable of fitting the job.

Thus, reformation to the conventional teaching method is needed to cultivate high qualified auditors. The setting up of a sophisticated teaching system is essential to developing students' innovative ability and manual operation capacity, flexibly linking theoretical knowledge and practical application, then elevating their learning initiatives and enthusiasm.

There are three points turning the conventional teaching method to the new. First is the transform of class subject. Students become the center of the class, which should now focuses on warming up their learning initiatives and independent thinking abilities.

Second is the changing of thinking mode, from convergent thinking to divergent thinking. This could develop the extensity and profundity of students' thinking, leading them following the hotspot and preceding issues.

The third one is the convert of teaching method. By dissecting and interpreting real cases gathered by teachers detailedly, teachers summarize, interpret and elevate teaching content into theory in the use of Case-teaching, cultivating students' manual practical ability and synthetic analysis ability.

\section{References}

[1] Wally Smieliauskas,jiang junyi ,Chen wei. On audit evidence and audit risk[J].Journal of Nanjing Audit University. 2013(03).

[2] Dr.Susela Devi.Competent Professional Accountants and The Challenges For Professional Accountancy Bodies:A CaseStudy. CAPA . 2004.

[3] WANG Qing-mei, ZHAO Ge.An Overview on Case Method Researches at Home and Abroad [J]. Journal of Ningbo University teaching method, 2009,03:7-11.

[4] Gelinas, Ulric J,Schwarzkopf, David L,Thibodeau, Jay C. Introducing Students to the Integrated Audit with "Auditing Alchemy, Inc."[J]. Journal of Information Systems . 2008 (2). 